\title{
Instruments for the functional assessment of elderly persons in palliative care: an integrative review
}

Vitória Marques de Sá Sanvezzo

Diego Santiago Montandon' Larissa Sapucaia Ferreira Esteves'

\section{Abstract}

Objective: to identify validated instruments that can be used for the functional assessment of elderly persons in Palliative Care. Method: an integrative review focused on identifying instruments for the functional assessment of elderly persons in palliative care was carried out by searching publications in periodicals indexed in seven electronic databases. Descriptors, keywords and Boolean operators were used for a cross-database search in November 2017. A total of 357 abstracts were identified, from which 53 articles were selected for reading, of which 21 met the inclusion criteria. Results: this strategy allowed the identification of eight scales and one test for the functional assessment of elderly persons in palliative care. Conclusion: eight scales and a functional test which also provide guidelines for improving the quality of life of elderly people in palliative care were identified, demonstrating that it is practically impossible to disassociate physical functional performance from social and psychological aspects.

Keywords: Elderly. Palliative Care. Assessment Instruments. 


\section{INTRODUCTION}

As life expectancy increases, resulting in an ever increasing number of people aged over 60 and who live to an advanced age, disease patterns in the final years of life also change, with more people dying from the effects of chronic than acute diseases. The chronification of a disease carries the risk of incapacitating sequelae, which can make the patient highly dependent in activities of daily living. There is no curative treatment for such diseases, but there are methods of control' ${ }^{1}$.

Due to such disorders, focusing on palliative care has become not only a matter of public health, but also of the humanization of care. Palliative Care focuses on improving the symptoms and quality of life (QoL) of people approaching the end of their lives, as well as providing support for their friends and family. It questions "technolatry" and major investment in technology for patients with no possibility of a cure, resulting in reflections on the necessary balance between science and humanism in the face of human mortality, in order to salvage the dignity of life ${ }^{2,3}$.

For the elderly population, the loss or reduction of functional status (bathing, dressing, transfers within their environment and performing instrumental activities of daily living) is closely associated with greater use of health services, isolation and residence in institutions; meaning that functionality is considered an important determinant of QoL among elderly people in Palliative Care ${ }^{4,5}$.

Functional evaluation in Palliative Care is therefore fundamental for monitoring the evolution of disease and represents a valuable element in the decision making process, prognosis, diagnosis and prevention of adverse effects associated with functional decline.

However, despite the importance of functional status for health outcomes, data on functionality are rarely collected during routine care. The aim of the present integrative review was therefore to identify instruments that can be used in the functional assessment of elderly persons in Palliative Care.

\section{METHOD}

An integrative review of the literature was performed. This is defined as a specific review method that aims to provide a comprehensive view on a particular topic and which is useful for clinical practice. The present study followed the steps recommended for the method: formulation of the research question, search of primary studies, data extraction, evaluation of primary studies, analysis and synthesis of results and presentation ${ }^{6}$.

The elaboration of the research question was based on the PICO strategy, in which "P" refers to the study population (elderly); "I" to the intervention studied or the variable of interest (palliative care); "C" to the comparison with another intervention (not used in this study) and "O" which refers to the outcome of interest (instrument of functional assessment $)^{7}$. Thus, the guiding question of this integrative review was: "What instruments are available for the functional assessment of elderly persons in Palliative Care?"

The search for primary studies was performed in seven databases: PubMed, of the National Library of Medicine; Cumulative Index to Nursing and Allied Health Literature (CINAHL); Latin American and Caribbean Health Sciences Literature - LILACS; EMBASE; Physiotherapy Evidence Database PEDro; Web of Science; and SCOPUS.

Controlled descriptors, keywords and their synonyms, and Boolean operators were used for cross-referencing in the databases as follows: PubMed (MeSH) - [(Aged) AND (Palliative care)] AND [(Assessment instruments)]; LILACS (DeCS - Descriptors in Health Science): "Idoso" AND "Cuidados Paliativos" OR "Cuidado paliativo" AND "Inquéritos e Questionários"; CINAHL (Research by words): "Aged" OR "Elderly" AND "Palliative care" AND "Assessment instruments" OR "Tool" AND "validation studies" OR "Validation"; EMBASE: (Palliative care) AND (Assessment instruments); PEDro: "Aged" AND "palliative care" AND "assessment instruments"; Web of Science: "Aged" OR "Elderly" AND "Palliative care" 
AND “Assessment instruments" OR “Tool” AND "validation studies" OR "Validation"; SCOPUS: "Aged" AND "palliative care" AND "assessment instruments".

The articles that dealt with instruments for the functional assessment of patients in palliative care were included; although the study focused on the elderly population, instruments that did not specifically mention the elderly were included to ensure that this population is also implicitly included in the evaluation criteria of these instruments. Limits on date and language of publication were not applied to ensure the study was as comprehensive as possible. Articles that did not elucidate the use of instruments focused directly on the patient or on palliative care were excluded.
The search for the primary studies in the selected databases occurred in November 2017 and was carried out by a librarian under the supervision of the authors of the present integrative review.

A total of 472 primary studies were identified, of which 182 were from PubMed; 108 from CINAHL; 03 from LILACS; 42 from EMBASE; 08 from PEDro; 88 from the Web of Science; and 41 from SCOPUS. A total of 115 repeated studies were excluded using an electronic manager of bibliographical references. The abstracts of the studies were read, from which 305 were excluded, resulting in an initial sample of 53 articles that were read in their entirety prior to the final selection of 21 primary studies. The process of screening the articles is shown in the flowchart (Figure 1), as recommended by the PRISMA group ${ }^{7}$.

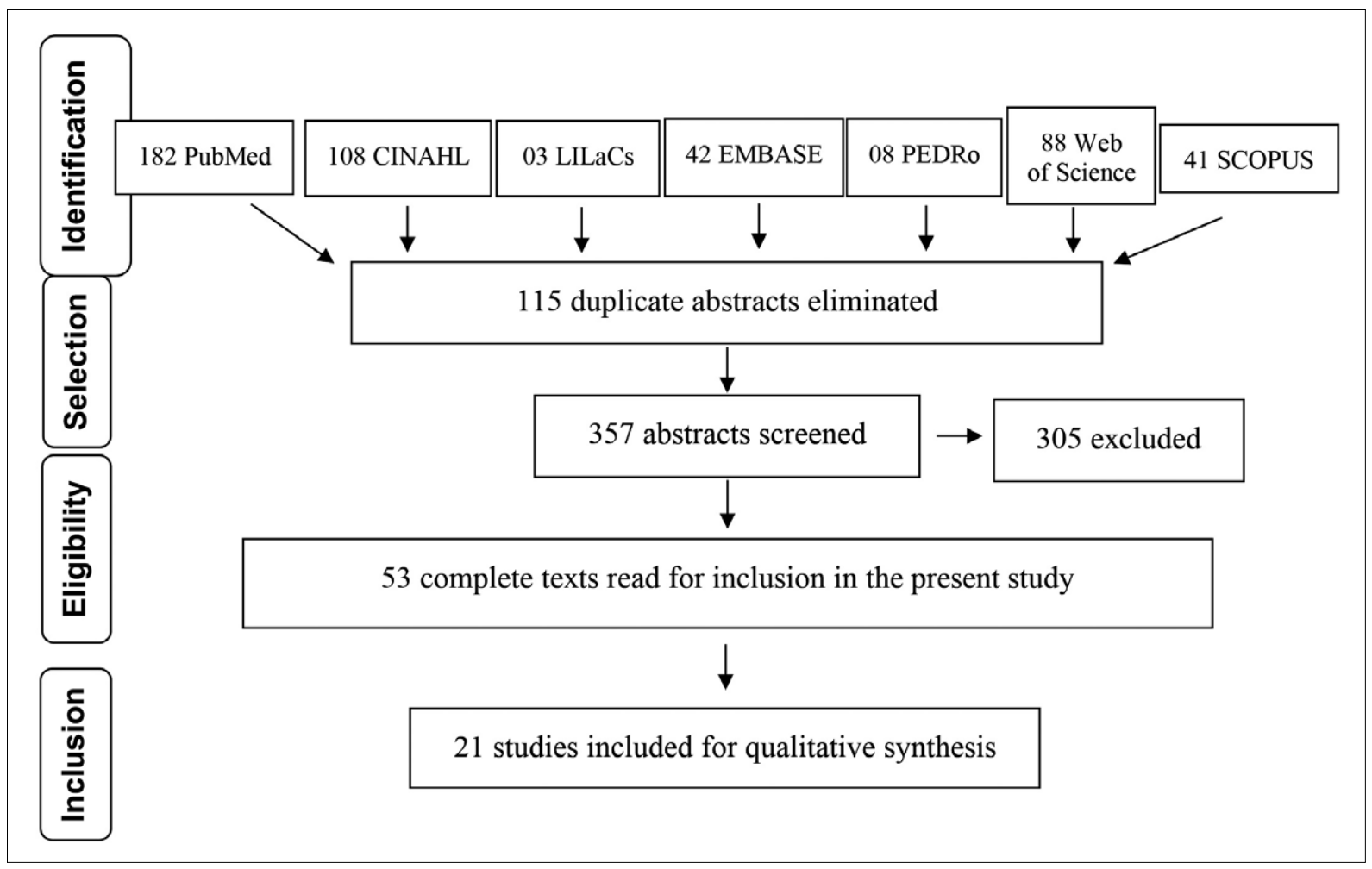

Figure 1. Flowchart of selection of studies found. Presidente Prudente, Sao Paulo, 2018. 
Data extraction was performed after each of the selected articles was read, and the relevant aspects were synthesized, such as: year of publication, country where study was performed, journal title, level of evidence and instruments for the functional assessment of elderly persons in palliative care.

For the evaluation of the primary studies included in the present review, a validated instrument was used. The classification of the level of evidence followed the recommendations in literature ${ }^{7,8}$, where: level I - systematic review or meta-analysis, randomized controlled trials; level II - evidence of at least one well-delineated randomized controlled clinical trial; level III - studies with well-delineated clinical trial methods without randomization; level IV - evidence of well-delineated cohort and case control study; level V - systematic reviews of descriptive and qualitative studies; level VI evidence of a single descriptive or qualitative study and level VII: opinions of experts and authorities in the area studied.

The analysis and synthesis of the results were carried out in order to answer the guiding question of this investigation, the presentation of which follows the recommendations of the minimum set of items for evidence-based reports compiled by PRISMA ${ }^{7,8}$, and which was registered in the PROSPERO system of literature reviews under number 77865 in August 2017.

\section{RESULTS}

In order to respond to the enquiry of this study, information related to the year of publication, the country where the research was carried out, the publication title, the level of evidence and the assessment instruments cited in each study to measure the functionality of elderly persons in palliative care were compiled (Table 1).

Chart 1. Characterization of primary studies selected by year, country, publication title, level of evidence and assessment instrument. Presidente Prudente, São Paulo, 2018.

\begin{tabular}{|l|l|l|l|l|l|}
\hline $\mathrm{N}^{\circ}$ & Year & Country & Title of Publication & $\begin{array}{l}\text { Level of } \\
\text { evidence }\end{array}$ & Assessment Instrument \\
\hline 1 & 2017 & Australia & $\begin{array}{l}\text { Recognizing older frail } \\
\text { patients near the end of } \\
\text { life: What's next? }\end{array}$ & V & $\begin{array}{l}\text { Comprehensive Geriatric Assessment - CGA } \\
\text { Frailty Index (FI) } \\
\text { Fried's frailty phenotype } \\
\text { Clinical Frailty Scale (CFS) Fatigue Resistance Ambulation } \\
\text { Illness Loss of weight (FRAIL) scale } \\
\text { Groningen Frailty Indicator (GFI) EAS Ycare-TOS } \\
\text { Edmonton Frailty Scale (EFS) } \\
\text { Identification of Seniors at Risk (ISAR) } \\
\text { FRAIL-NH scale }\end{array}$ \\
\hline 2 & 2016 & Poland & $\begin{array}{l}\text { Functional } \\
\text { assessment of the } \\
\text { elderly with the } \\
\text { use of EASYCare } \\
\text { Standard 2010 and } \\
\text { Comprehensive } \\
\text { Geriatric } \\
\text { Assessment }\end{array}$ & III & $\begin{array}{l}\text { II ASYCare Standard 2010; Comprehensive Geriatric } \\
\text { Assesment - CGA }\end{array}$ \\
\hline
\end{tabular}


Continuation of Chart 1

\begin{tabular}{|c|c|c|c|c|c|}
\hline $\mathrm{N}^{\mathrm{o}}$ & Year & Country & Title of Publication & $\begin{array}{l}\text { Level of } \\
\text { evidence }\end{array}$ & Assessment Instrument \\
\hline 3 & 2005 & USA & $\begin{array}{l}\text { Assessment } \\
\text { Instruments } \\
\text { Clinics in Geriatric } \\
\text { Medicine }^{11}\end{array}$ & $\mathrm{~V}$ & $\begin{array}{l}\text { Karnofsky Performance Scale } \\
\text { Activities of Daily Living (ADL) } \\
\text { Instrumental Activities of Daily Living (IADL) } \\
\text { Eastern Cooperative Oncology Group Perfomance Status Scale } \\
\text { (ECOG Perfomance Status) Rapid Disability Rating Scale } \\
\text { (RDRS) } \\
\text { Health Assessment Questionnaire (HAQ) } \\
\text { Functional Independence Measure (FIM) } \\
\text { Sickness Impact Profile (SIP) } \\
\text { Time Up and Go test (TUG) } \\
\text { European Organisation for Research and Treatment of Cancer } \\
\text { Quality of Life Questionnaire Core } 30 \text { items (EORTC- } \\
\text { QLQ-C30) } \\
\text { Functional Assessment of Chronic Illness Therapy (FACIT) } \\
\text { McGill Quality of Life Questionnaire (MQL) }\end{array}$ \\
\hline 4 & 2003 & USA & $\begin{array}{l}\text { The RAI-PC: } A n \\
\text { assessment instrument } \\
\text { for palliative care in all } \\
\text { settings }{ }^{12}\end{array}$ & III & RAI-PC \\
\hline 5 & 2016 & Belgium & $\begin{array}{l}\text { An instrument } \\
\text { to collect data } \\
\text { on frequency } \\
\text { and intensity of } \\
\text { symptoms in } \\
\text { older palliative } \\
\text { cancer patients: A } \\
\text { development and } \\
\text { validation study }\end{array}$ & IV & $\begin{array}{l}\text { Memorial Symptom Assessment Scale } \\
\text { Edmonton Symptom Assessment System } \\
\text { Rotterdam Symptom Checklist European Organisation } \\
\text { for Research and Treatment of Cancer Quality of Life } \\
\text { Questionnaire Core } 30 \text { items (EORTC-QLQ-C30) } \\
\text { Hospice Quality of Life Index McGill Quality of Life (MQOL) } \\
\text { Functional Assessment of Chronic Illness Therapy and } \\
\text { Spiritual well-being } \\
\text { Symptom Assessment To Improve Symptom Control For } \\
\text { Institutionalized Elderly (SATISFIE) }\end{array}$ \\
\hline 6 & 2016 & Belgium & $\begin{array}{l}\text { Usefulness, feasibility } \\
\text { and face validity of the } \\
\text { interRAI Palliative } \\
\text { Care instrument according } \\
\text { to care professionals } \\
\text { in nursing homes: } A \\
\text { qualitative study }\end{array}$ & IV & RAI-PC \\
\hline 7 & 2014 & Norway & $\begin{array}{l}\text { The last three days of } \\
\text { life: a comparison of } \\
\text { pain management in the } \\
\text { young old and the oldest } \\
\text { old hospitalized patients } \\
\text { using the Resident } \\
\text { Assessment Instrument } \\
\text { for Palliative Care }\end{array}$ & III & RAI-PC \\
\hline 8 & 2014 & Canada & $\begin{array}{l}\text { Care planning needs } \\
\text { of palliative home care } \\
\text { clients: Development of } \\
\text { the interRAI palliative } \\
\text { care assessment clinical } \\
\text { assessment protocols } \\
(\mathrm{CAPs})^{16}\end{array}$ & IV & PC interRAI \\
\hline
\end{tabular}


Continuation of Chart 1

\begin{tabular}{|c|c|c|c|c|c|}
\hline $\mathrm{N}^{\mathrm{o}}$ & Year & Country & Title of Publication & $\begin{array}{l}\text { Level of } \\
\text { evidence }\end{array}$ & Assessment Instrument \\
\hline 9 & 2008 & Canada & $\begin{array}{l}\text { Reliability of the } \\
\text { interRAI suite of } \\
\text { assessment instruments: } \\
\text { a } 12 \text {-country study of } \\
\text { na integrated health } \\
\text { information system }\end{array}$ & III & $\begin{array}{l}\text { InterRAI Long Term Care Facility (interRAI } \\
\text { LTCF); InterRAI Home Care (interRAI HC); } \\
\text { InterRAI Post-acute Care (interRAI PAC); } \\
\text { InterRAI Palliative Care (interRAI PC); } \\
\text { InterRAI Mental Health (interRAI MH). }\end{array}$ \\
\hline 10 & 2015 & USA & $\begin{array}{l}\text { Measuring End- } \\
\text { of-Life Care and } \\
\text { Outcomes in } \\
\text { Residential Care/ } \\
\text { Assisted Living and } \\
\text { Nursing Homes }^{18}\end{array}$ & III & $\begin{array}{l}\text { Family Perceptions of Physical and Family Care giver; } \\
\text { Communication and the End of Life in Dementia (EOLD); } \\
\text { Satisfaction With Care and; } \\
\text { EOLD-Symptom Management; } \\
\text { EOLD-Comfort Assessment in Dying; } \\
\text { Mini-Suffering State Examination (MSSE). }\end{array}$ \\
\hline 11 & 2016 & Turkey & $\begin{array}{l}\text { Reliability and validity } \\
\text { of the Turkish version of } \\
\text { the EORTC QLQ- } \\
\text { C15-PAL for patients } \\
\text { with advanced cancer }\end{array}$ & IV & $\begin{array}{l}\text { European Organization for Research (EORTC QLQ); } \\
\text { Treatment of Cancer Quality of Life Questionnaire (C15-PAL). }\end{array}$ \\
\hline 12 & 2011 & $\begin{array}{l}\text { United } \\
\text { Kingdom }\end{array}$ & $\begin{array}{l}\text { Assessing quality-of- } \\
\text { life in older people in } \\
\text { care homes }^{20}\end{array}$ & IV & $\begin{array}{l}\text { Evaluation of the Individual Quality of Life-Direct Weighting } \\
\text { (SEIQoL-DW) }\end{array}$ \\
\hline 13 & 2010 & Sweden & $\begin{array}{l}\text { The Assessment of } \\
\text { Quality of life at the } \\
\text { End of Life (AQEL) } \\
\text { questionnaire: a brief but } \\
\text { comprehensive instrument } \\
\text { for use in patients with } \\
\text { cancer in palliative care }{ }^{21}\end{array}$ & IV & $\begin{array}{l}\text { European Organisation for Research and Treatment of Cancer } \\
\text { Quality of Life Questionnaire Core } 30 \text { items (EORTC- } \\
\text { QLQ-C30) }\end{array}$ \\
\hline 14 & 2007 & USA & $\begin{array}{l}\text { Measuring Patient- } \\
\text { Oriented Outcomes } \\
\text { in Palliative Care: } \\
\text { Functionality and } \\
\text { Quality of Life }\end{array}$ & $\mathrm{V}$ & $\begin{array}{l}\text { Karnofsky Performance Scale (KPS) } \\
\text { Palliative Performance Scale (PPS) } \\
\text { Short-Form Health Survey (SF-36) } \\
\text { European Organisation for Research and Treatment of Cancer } \\
\text { Quality of Life Questionnaire Core } 30 \text { items (EORTC- } \\
\text { QLQ-C30) } \\
\text { The Functional Assessment of Cancer Therapy-General (FACT-G) } \\
\text { The Quality of Life index (QLI) } \\
\text { The Cancer Rehabilitation Evaluation System (CARES) } \\
\text { McGill Quality of Life Questionnaire (MQOL) Evaluation of } \\
\text { Individual Quality of Life (SEIQoL) } \\
\text { The Functional Living Index-Cancer (FLIC) }\end{array}$ \\
\hline 15 & 2008 & Canada & $\begin{array}{l}\text { Palliative care } \\
\text { rehabilitation survey: } \\
\text { a pilot study of } \\
\text { patients' priorities for } \\
\text { rehabilitation goals }{ }^{23}\end{array}$ & IV & $\begin{array}{l}\text { Canadian Model of Occupational Performance } \\
\text { (CMOP) }\end{array}$ \\
\hline 16 & 2007 & USA & $\begin{array}{l}\text { Quality-of-life } \\
\text { Assessment in } \\
\text { Palliative Care }{ }^{24}\end{array}$ & VI & $\begin{array}{l}\text { Karnofsky Score } \\
\text { Edmonton Symptom Assessment; Memorial Symptoms } \\
\text { Assessment Scale; European Organization for Research and } \\
\text { Treatment of Cancer Questionnaire (EORTC-QLQ-C30) } \\
\text { Quality and Quantity of Life Short Questionnaire; } \\
\text { Cambridge Palliative Assessment Schedule. }\end{array}$ \\
\hline
\end{tabular}


Continuation of Chart 1

\begin{tabular}{|c|c|c|c|c|c|}
\hline $\mathrm{N}^{\mathrm{o}}$ & Year & Country & Title of Publication & $\begin{array}{l}\text { Level of } \\
\text { evidence }\end{array}$ & Assessment Instrument \\
\hline 17 & 2005 & Australia & $\begin{array}{l}\text { Measuring symptom } \\
\text { distress among } \\
\text { frail elders capable } \\
\text { of providing self } \\
\text { reports }^{25}\end{array}$ & III & Symptom Assessment Scale \\
\hline 18 & 2016 & Belgium & $\begin{array}{l}\text { Frequency and } \\
\text { intensity of symptoms } \\
\text { and treatment } \\
\text { interventions in } \\
\text { hospitalized older } \\
\text { palliative cancer } \\
\text { patients: a multicenter } \\
\text { cross-sectional study }^{26}\end{array}$ & IV & $\begin{array}{l}\text { Assessment Symptoms Palliative Elderly (ASPE); } \\
\text { Symptom Intervention Palliative Elderly (SIPE); }\end{array}$ \\
\hline 19 & 2014 & Holland & $\begin{array}{l}\text { Symptoms and } \\
\text { treatment when } \\
\text { death is expected in } \\
\text { dementia patients } \\
\text { in long-term care } \\
\text { facilities }^{27}\end{array}$ & III & $\begin{array}{l}\text { Pain Assessment In Advanced Dementia (PAINAD) } \\
\text { Discomfort Scale-Dementia Alzheimer type (DS-DAT); } \\
\text { End-of-Life in Dementia scales- Comfort Assessment in Dying } \\
\text { (EOLD-CAD); } \\
\text { Mini Suffering State Examination (MSSE) }\end{array}$ \\
\hline 20 & 2014 & Belgium & $\begin{array}{l}\text { A Comparative Analysis } \\
\text { of Comprehensive } \\
\text { Geriatric Assessments } \\
\text { for Nursing Home } \\
\text { Residents Receiving } \\
\text { Palliative Care: } A \\
\text { Systematic Review } \\
\end{array}$ & IV & $\begin{array}{l}\text { InterRAI Palliative Care (interRAI PC); } \\
\text { McMaster Quality of Life Scale; } \\
\text { Missoula-VITAS Quality of Life Index-Revised (MVQOLI-R); } \\
\text { Modified Quality of Life Concerns in the End of Life } \\
\text { Questionnaire (mQOLC-E); } \\
\text { McMaster Quality of Life Scale (MQLS); } \\
\text { InterRAI PC and Former Minimum Data Set; } \\
\text { Palliative Care Outcome Scale (POS); }\end{array}$ \\
\hline 21 & 2013 & USA & $\begin{array}{l}\text { A Symptom } \\
\text { assessment in elderly } \\
\text { cancer patients } \\
\text { receiving palliative } \\
\text { care }^{29}\end{array}$ & VI & $\begin{array}{l}\text { Memorial Symptom Assessment Tool; } \\
\text { Edmonton Symptom Assessment; MD Anderson Symptom } \\
\text { Inventory; } \\
\text { European Organization for Research and Treatment of } \\
\text { Cancer's Quality of Life Core Questionnaire (EORTC } \\
\text { QLQ-C30); } \\
\text { Condensed Memorial Symptom Assessment Scale Rounding Tool; }\end{array}$ \\
\hline
\end{tabular}

\section{DISCUSSION}

This integrative review sought to evaluate primary studies in the seven main databases used as references by health professionals in order to support the development of studies on palliative care in the context of gerontology. Applying the PRISMA protocol adds quality to the article, as such guidelines are focused on helping authors reduce publication bias and are a likely marker of rigor of conduct in Evidence Based Practice (EBP) ${ }^{30}$. From an overall perspective, all 21 articles analyzed are written in English and are based in countries considered to be developed and which have high longevity rates, implying that the Longevity Revolution is a reality that has been widely discussed and studied, unlike Brazil, which remains in the process of aging ${ }^{31,32}$.

As for the publication dates, 12 articles were written in the last five years (from 2013); four articles between five and ten years ago (from 2008 to 2012) and five articles were published more than ten years ago (prior to 2007). These data demonstrate the use of current studies and, therefore, the relevance of the topic, as the constant updating of studies is a differentiating factor in research and clinical 
practices: as the EBP movement itself breaks paradigms regarding the gaps between research and practice by promoting evidence from clinical surveys over the opinions of experts and institutions ${ }^{33,34}$.

Also with regard to EBP, Levels of Evidence (LE) were applied and used to analyze the methodological route of the studies selected from the databases. In this EBP, articles classified as LE III and IV (seven and nine articles, respectively) and articles with LEs of between V and VI (three and two articles) predominated, or in other words, high methodological levels were not identified. While this is a worrying finding, as Systematic Reviews and Metanalyses represent a gold standard in EBP, it is important to realize that the guiding question of this analysis: "What instruments are available for the functional assessment of elderly persons in Palliative Care?" is normally answered through observational, methodological studies - for the validation of the instruments, integrative and narrative reviews, methodologies contemplated in the LE found ${ }^{34}$.

To better understand the purposes of the scales evaluated, the discussion can be divided into two nuclei, namely: scales that assess the functionality and physical performance of patients in Palliative Care and scales that assess QoL and consequently include in their domains indexes that evaluate functionality as part of biopsychosocial care.

With regard to QoL, the European Organization for the Research and Treatment of Cancer Questionnaire (EORTC-QLQ-C30) and the InterRAI Palliative Care (RAI-PC) appeared in the greatest number of studies, with seven $(33 \%)$ and six (28\%) indications respectively; while the Edmonton Symptom Assessment, the Memorial Symptom Assessment and the McGill Quality of Life Questionnaire (MQoL) scales were found in three $(14 \%)$ articles. The Enlarged Geriatric Assessment and the End-of-Life in Dementia - Comfort Assessment in Dying (EOLD-CAD) and Evaluation of the Individual Quality of Life-Direct Weighting (SEIQoL-DW) scales were used to evaluate QoL in two $(9 \%)$ studies; the other scales appear in only one $(4 \%)$ of the studies.

Regarding the assessment of functionality and physical performance, eight distinct scales and one test were identified and will now be discussed separately in order to better answer the research enquiry.

The Karnofsky Performance Scale (KPS), developed in 1948, is considered to be objective, practical and has undergone more than 50 years of validation with oncology and non-cancer patients. The level of functionality is assessed by the health professional with a percentage ranging from $100 \%$ (normal, no health complaints, no evidence of illness) to $0 \%$ (death); as it is strictly related to the levels of distress caused by symptoms, KPS is often used as a prognostic tool to predict life expectancy $y^{11,35,36}$.

The Palliative Perfomance Scale (PPS) is based on a premise similar to the KPS. The original version, which consists of a one-dimensional scale, has been expanded to include the dimensions of mobility, activity, evidence of illness, self-care, intake, and conscious level. A health professional classifies each dimension by assigning a value of $100 \%$ to $0 \%$ (death), with $10 \%$ indicating the lowest level of functioning. Classifications of mobility, activity and evidence of disease dominate over the latter variables. For example, a patient who remains lying down or sitting all day (50\% mobility score) but who has normal intake and normal conscious level $(100 \%$ intake and conscious level) has an overall PPS score of $50 \%$. Therefore, researchers and clinicians who plan to use PPS version 2 should consider whether this hierarchy reflects priorities for evaluating patients. The scale successfully predicts the need for hospital care; declining rates are associated with a deteriorating condition and death, while stable scores are associated with discharge and home care ${ }^{35}$.

The Katz and Lawton Index separately assesses the need for assistance in both basic and instrumental activities of daily living. The Law ton \& Brody index, developed in 1969, allows the evaluation of the autonomy of the elderly to perform instrumental activities of daily living (AIVD): telephone use, shopping, preparation of meals, household chores, washing of clothes, use of means of transportation, medication management and financial responsibility. For each IADL, the elderly person receives a score of dependent (1 point), needing assistance for activities ( 2 points) or independent ( 3 points). At the end, those who score between 19 and 27 points are considered independent, those who score from 10 to 18 points 
semi-independent, and those who score below 9 points dependent ${ }^{11,37,38}$.

In the Katz Index, the elderly are evaluated through six parameters (ability to bathe, dress, go to the toilet, transfer, continence and food). The score varies from 0 (zero) to 3 (three), and 0 points are awarded for each activity that the elderly person can achieve without needing help, 1 and 2 points if they need nonhuman and human help respectively, and 3 points if dependent for that activity. After the evaluation, the points are added together and the individual is classified into one of three categories: independence ( $<6$ points); moderate dependence ( 7 to 16 points) and severe dependence (over 16 points) ${ }^{11,37,38}$.

The Rapid Disability Rating Scale (RDRS) is also responsible for evaluating instrumental activities of daily living. It corresponds to a four-point scale, and includes eight items related to activities of daily living, three in mental capacity and one on changes in diet, continence, medications and mobilization in bed; it is particularly suitable for elderly patients, and can be applied in hospitals and nursing homes, but it is little used in clinical practice. The degree of need for day-to-day help, the degree of disability and the degree of special problems are taken into account, with the highest score being 54 and higher scores indicating greater difficulty ${ }^{11,39}$.

The Health Assessment Questionnaire (HAQ) is an instrument developed three decades ago by James F. Fries and colleagues from Stanford University as a self-reported assessment model that analyzes physical function. It has strong reliability and validity, and is widely used in patients with rheumatic diseases, HIV/ AIDS and elderly people. It is a good descriptive tool, but may be less appropriate for measuring clinical changes ${ }^{11,40}$.

The Functional Independence Measure (FIM) aims to assess the burden of care required by an individual, and is an instrument for assessing disability with various types of functional restrictions. It consists of 18 items that evaluate six different areas comprising motor and cognitive items and has a graded system of patient response that alternates from one to seven; the total score ranges from 18 to 126 , with a high score synonymous with greater independence. It is well validated but its use is limited in clinical practice except in rehabilitation settings ${ }^{11,41}$.
The Sickness Impact Profile (SIP) is designed to measure patients' dysfunction through their daily behavior. This scale focuses on the patient's ability to move within the home, leave the home and use transportation. Its overall result ranges from $0 \%$ to $100 \%$, where $0 \%$ represents completely healthy and $100 \%$ completely dependent patients. It was developed at the University of Washington in Seattle, USA. It is now used by numerous institutions around the world and is the official QoL questionnaire at Johns Hopkins University in Baltimore. The Questionnaire consists of 136 yes/no questions that represent specific activities divided into twelve general categories; its use is usually connected to research ${ }^{11,42}$.

The Timed Up and Go (TUG) test involves the observation of the patient getting up from a sitting position, walking ten feet, turning, returning to the chair, and sitting down. A score of more than 20 seconds should lead to further evaluation. It is a simple and reliable measure of mobility and can be useful for following functional decline over a period of time ${ }^{11}$.

The Short-Form Health Survey (SF-36) consists of eight subscales that measure limitations in physical and social activities caused by physical health and emotional problems, as well as physical pain, general mental health, vitality and general health perceptions $^{22}$.

In general, as a result of the analysis, it was identified that QoL assessment is linked to Palliative Care as an essential part of a care plan, and is a factor that directly influences the functionality of a patient.

It is notable that the development of the World Health Organization Quality of Life instrument (WHOQOL) was the first step in finding a consensus on definitions of QoL. The World Health Organization brought together experts from around the world who defined QOL as the individual's perception of their position in life in the context of the culture and value system in which they live and in relation to their goals, expectations, standards and concerns. The most important question is the patient's perception of the cultural, social and environmental context in which they are inserted, interrelating the environment with physical, psychological, independence, social relations and personal beliefs ${ }^{43}$. 
Also included in the instruments that measure QoL is the WHOQOL-old, modified for the elderly, which evaluates QoL through six domains: assessment of sensory functioning, autonomy, present, past and future activities, social participation, death and dying and intimacy ${ }^{44}$. It is perceived that, even though it is an instrument directed at subjective questions (such as death and dying), autonomy and functionality are included as extremely relevant points for the wellbeing of this population.

Working in an integrative manner therefore requires the efforts of an interdisciplinary team that is prepared to extrapolate the hegemonic, biomedical model. Specific concepts of gerontology and palliative care such as geriatric syndromes, rehabilitation, frailty, independence and autonomy require that professionals work in a broader manner, focused on the biopsychosocial model; in this case, the concept of health is related to maintaining autonomy and functionality even in the presence of chronic diseases ${ }^{31}$.

It is known, however, that this model of work is strongly linked to the structuring of networks and training of professionals for extended clinical care. As a resource to enable this kind of care, assessments can be a great support for health professionals in preparing an adequate care plan for the elderly population in Palliative Care.

One limitation of the present study was the impossibility of verifying if the scales presented are already available in Portuguese or if they are validated for scientific use in Brazil. The relevance of the research should be highlighted, however, as it brings together up to date evidence from different instruments to assess the functionality of the elderly in palliative care in very specific scenarios.

\section{CONCLUSION}

The search for scientific evidences in seven databases, with the selection of 21 primary studies through the rigid methodological design of Evidence Based Practice, allowed the identification of 19 instruments of assessment, of which eight scales and one test were recognized as suitable for the functional assessment of elderly patients in palliative care.

This analysis allowed it to be understood that functional scales also provide guidelines for improving the Quality of Life of elderly people in Palliative Care, representing an alternative of evaluation when other resources are not available or are not known to the professionals of the team. In addition, the study demonstrated that it is practically impossible to disassociate physical functionality from social and psychological factors.

There is therefore a need to verify the availability of these instruments in Portuguese and for use in Brazil. Now studies should be carried out with a methodology of translating and validating these instruments in order to provide reliable tools for the assessment of the elderly in palliative care.

Training of the multiprofessional team and changes in professional education are necessary to allow a broader view of the elderly in Palliative Care, in order to direct the results of the scales towards humanized and integral care.

\section{REFERENCES}

1. Camargos MCS, Gonzaga MR. Viver mais e melhor?: estimativas de expectativa de vida saudável para a população brasileira. Cad Saúde Pública [Internet]. 2015 [acesso em 07 fev. 2018];31(7):146072. Disponível em: http://www.scielo.br/pdf/csp/ v31n7/0102-311X-csp-31-7-1460.pdf

2. Hall S, Petkova H, Tsouros AD, Costantini M, Higginson IJ. Palliative care for older people: better practices. Copenhagen: WHO; 2011.
3. Brown RT, Komaiko KD, Shi Y, Fung KZ, Boscardin WJ, Au-Yeung A, et al. Bringing functional status into a big data world: Validation of national veterans affairs functional status data. PloS ONE [Internet]. 2017 [acesso em 28 de jun. 2018];12(6):1-9. Disponível em: https://journals.plos.org/plosone/ article?id=10.1371/journal.pone. 0178726 
4. Matsumoto DY. Cuidados paliativos: conceito, fundamentos e princípios. In: Carvalho RT, Parsons HA. Manual de Cuidados Paliativos. São Paulo: ANCP: 2012. p. 23-30.

5. Helbostad JL, Holen JC, Jordhoy MS, Ringdal GI, Oldervoll L, Kaasa S. A First step in the development of international self-report instrument for physical functioning in palliative cancer care: a systematic literature review and an expert opinion evaluation study. J Pain Symptom Manage. 2009;37(2):195-205.

6. Melnyk BM, Fineout-Overhol E. Evidence-based practice in nursing \& healthcare: a guide to best practice. Philadelphia: Lippincott Williams \& Wilkins; 2011.

7. Liberati A, Altman DG, Tetzlaff J, Mulrow C, Gotzsche PC, Loannidis JPA, et al. The PRISMA statement for reporting systematic reviews and meta-analyses of studies that evaluate health care interventions: explanation and elaboration. BMJ. 2009;339:1-55.

8. Akobeng AK. Principles of evidence based medicine. Arch Dis Child. 2005;90(8):837-40.

9. Cardona-Morrell M, Lewis E, Suman S, Haywood C, Williams M, Brousseau AA, et al. Recognising older frail patients near the end of life: What next? Eur J Intern Med. 2017;45(1):84-90.

10. Talarska D, Pacholska R, Strugała M, WieczorowskaTobis K. Functional assessment of the elderly with the use of EASY-Care Standard 2010 and Comprehensive Geriatric Assessment. Scand j Caring Sci. 2016;30(2):419-26.

11. Arseven A, Chang CH, Arseven OK, Emanuel LL. Assessment Instruments. Clin Geriatr Med. 2005;21(1):121-46

12. Steel K, Ljunggren G, Topinkova E, Morris JN, Vitale C, Parzuchowski J, et al. The RAI-PC: an assessment instrument for palliative care in all settings. Am J Hosp Palliat Med. 2003;20(3):211-9.

13. van Lancker A, Beeckman D, Verhaeghe S, van Den Noortgate N, Grypdonck M, Van Hecke A. An instrument to collect data on frequency and intensity of symptoms in older palliative cancer patients: a development and validation study. Eur J Oncol Nurs. 2016;21:38-47.

14. Hermans K, Spruytte N, Cohen J, Van Audenhove C, Declercq A. Usefulness, feasibility and face validity of the interRAI Palliative Care instrument according to care professionals in nursing homes: a qualitative study. Int J Nurs Stud. 2016;62:90-9.

15. Steindal SA, Bredal IS, Ranhoff AH, Sorbye LW, Lerdal A. The last three days of life: a comparison of pain management in the young old and the oldest old hospitalised patients using the Resident Assessment Instrument for Palliative Care. Int J Older People Nurs. 2015;10(4):263-72.
16. Freeman S, Hirdes JP, Stolee P, Garcia J, Smith TF, Steel K, et al. Care planning needs of palliative home care clients: development of the interRAI palliative care assessment clinical assessment protocols (CAPs). BMC Palliat Care. 2014;13(1):58-70.

17. Hirdes JP, Ljunggren G, Morris JN, Frijters DH, Soveri HF, Gray L, et al. Reliability of the interRAI suite of assessment instruments: a 12-country study of an integrated health information system. BMC Health Serv Res. 2008;8(1):277-86.

18. Zimmerman S, Cohen L, van Der Steen JT, Reed D, van Soest-Poortvliet MC, Hanson LC, et al. Measuring end-of-life care and outcomes in residential care/assisted living and nursing homes. J Pain Symptom Manag. 2015;49(4):666-79.

19. Ozcelik H, Guzel Y, Sonmez E, Aksoy F, Uslu R. Reliability and validity of the Turkish version of the EORTC QLQ-C15-PAL for patients with advanced cancer. Palliat Support Care. 2016;14(6):628-34.

20. Hall S, Opio D, Dodd RH, Higginson IJ. Assessing quality-of-life in older people in care homes. Age Ageing. 2011;40(4):507-12.

21. Henoch I, Axelsson B, Bergman B. The Assessment of Quality of life at the End of Life (AQEL) questionnaire: a brief but comprehensive instrument for use in patients with cancer in palliative care. Qual Life Res. 2010;19(5):739-50.

22. Granda-Cameron C, Viola SR, Lynch MP, Polomano RC. Measuring patient-oriented outcomes in palliative care: functionality and quality of life. Clin J Oncol Nurs. 2008;12(1):65-77.

23. Schleinich MA, Warren S, Nekolaichuk C, Kaasa T, Watanabe S. Palliative care rehabilitation survey: a pilot study of patients' priorities for rehabilitation goals. Palliat Med. 2008;22(7):822-30.

24. Brasel KJ. Quality-of-life assessment in palliative care. Am J Hosp Palliat Med. 2007;24(3):231-5.

25. Toye C, Walker H, Kristjanson LJ, Popescu A, Nightingale E. Measuring symptom distress among frail elders capable of providing self reports. Nurs Health Sci. 2005;7(3):184-91.

26. van Lancker A, Beeckman D, van Den Noortgate N, Verhaeghe S, van Hecke A. Frequency and intensity of symptoms and treatment interventions in hospitalized older palliative cancer patients: a multicentre cross sectional study. J Adv Nurs. 2017;73(6):1455-66.

27. Klapwijk MS, Caljouw MA, van Soest-Poortvliet MC, van der Steen JT, Achterberg WP. Symptoms and treatment when death is expected in dementia patients in long-term care facilities. BMC geriatrics. 2014;14(1): 99-111. 
28. Hermans K, Mello JDA, Spruytte N, Cohen J, van Audenhove C, Declercq A. A comparative analysis of comprehensive geriatric assessments for nursing home residents receiving palliative care: a systematic review. J Am Med Dir Ass. 2014;15(7):467-76.

29. Pautex S, Berger A, Chatelain C, Herrmann F, Zulian GB. Symptom assessment in elderly cancer patients receiving palliative care. Crit Rev Oncol Hematol. 2003;47(3):281-6.

30. Galvão TF, Pansani TSA, Harrad D. Principais itens para relatar revisões sistemáticas e meta-análises: a recomendação PRISMA. Epidemiol Serv Saúde. 2015;24(2):335-42.

31. Miranda GMD, Mendes ACG, da Silva ALA. O envelhecimento populacional brasileiro: desafios e consequências sociais atuais e futuras. Rev Bras Geriatr Gerontol [Internet]. 2016 [acesso em 18 fev. 2018];19(3):507-19. Disponível em: http://www. redalyc.org/articulo.oa?id $=403846785012$

32. Kalache A. Respondendo à revolução da longevidade. Ciênc Saúde Colet [Internet]. 2014 [acesso em 18 fev. 2018];19(8):3306. Disponível em: http://www.redalyc. org/articulo.oa? $\mathrm{id}=63031151001$

33. Danski MTR, Oliveira GLR, Pedrolo E, Lind J, Johann DA . Importância da prática baseada em evidências nos processos de trabalho do enfermeiro. Ciênc Cuid Saúde. 2017;16(2):1-5.

34. Pedrosa K, Oliveira I, Feijão A, Machado R. Enfermagem baseada em evidência: caracterização dos estudos no Brasil. Cogitare Enfermagem [Internet] 2015 [acesso em 18 fev. 2018];20(4):733-41. Disponível em: https://revistas.ufpr.br/cogitare/ article/view/40768/26737

35. Cameron CG, Viola SR, Lynch P, Polomano RC. Measuring patient-oriented outcomes in palliative care: functionality and quality of life. Clin J Oncol Nurs. 2008;12(1):65-77.
36. Brasel KJ. Quality of life assessment in palliative care. Surg Palliat Care 2007;24(3):231-5.

37. Brasil. Ministério da Saúde, Secretaria de Atenção à Saúde, Departamento de Atenção Básica. Envelhecimento e saúde da pessoa idosa. Brasília, DF: Ministério da Saúde; 2006.

38. Bagueixa MAHL, Pimentel MH, Iglesias MJG. Fragilidade no idoso internado num Serviço de Ortopedia. Rev Port Ortop Traum [Internet]. 2017;[acesso em 28 jun. 2018];25(3):173-84. Disponível em: http://www.scielo.mec.pt/scielo.php?script $=$ sci_ arttext\&pid=S1646-21222017000300003\&lng=pt

39. Shantong J, Pingping L. Current development in elderly comprehensive assessment and research methods. BioMed Res Int. 2016:1-10.

40. Norton S, Fu B, Scott DL, Deighton C, Symmons DPM, Wailoo AJ, et al. Health Assessment Questionnaire disability progression in early rheumatoid arthritis: systematic review and analysis of two inception cohorts. Semin Arthritis Rheum. 2014;44:131-44.

41. Silva NPO, Martins LJNS, Ferreira BF, Cavalcanti FAC. Correlação entre independência funcional e qualidade de vida de pacientes com esclerose lateral amiotrófica. Cad Bras Ter Ocup. 2014;22(3):507-13.

42. Prcic A, Damir A, Osman H. "Sickness Impact Profile (SIP) Score, a Good Alternative Instrument for Measuring Quality of Life in Patients with Ileal Urinary Diversions." Acta Inform Med. 2013;21(3):160-5.

43. Vitorino L, Paskulin L, Vianna L. Qualidade de vida de idosos da comunidade e de instituições de longa permanência: estudo comparativo. Rev Latinoam Enferm [Internet]. 2013; [acesso em 18 fev. 2018]21(n. esp.):3-11. Disponível em: http://www.scielo.br/scielo. php?script=sci_arttext\&pid=S0104-11692013000700002

44. Silva PAB, Soares SM, Santos JFG, Silva B. Cut-off point for WHOQOL-bref as a measure of quality of life of older adults. Rev Saúde Pública. 2014;48(3):390-7. 